\title{
Inactivation of Human Pathogens during Phase II Composting of Manure-Based Mushroom Growth Substrate
}

\author{
JENNIFER D. WEIL, † CATHERINE N. CUTTER, ROBERT B. BEELMAN, AND LUKE F. LABORDE* \\ Department of Food Science, The Pennsylvania State University, 202 Food Science Building, University Park, Pennsylvania 16802, USA
}

MS 12-508: Received 10 November 2012/Accepted 5 April 2013

\begin{abstract}
Commercial production of white button mushrooms (Agaricus bisporus) requires a specialized growth substrate prepared from composted agricultural by-products. Because horse and poultry manures are widely used in substrate formulations, there is a need to determine the extent to which the composting process is capable of eliminating human pathogens. In this study, partially composted substrate was inoculated with a pathogen cocktail $\left(\log 10^{6}\right.$ to $10^{8} \mathrm{CFU} / \mathrm{g}$ ) containing Listeria monocytogenes, Escherichia coli O157:H7, and Salmonella. Pathogen and indicator-organism reductions were followed at temperatures that typically occurred during a standard 6-day phase II pasteurization and conditioning procedure. Controlled-temperature water bath studies at $48.8,54.4$, and $60^{\circ} \mathrm{C}$ demonstrated complete destruction of the three pathogens after $36.0,8.0$, and $0.5 \mathrm{~h}$, respectively. Destruction of L. monocytogenes and E. coli $\mathrm{O} 157: \mathrm{H} 7$ at $54.4^{\circ} \mathrm{C}$ occurred more slowly than E. coli, total coliforms, Enterobacteriaceae, and Salmonella. Microbial reductions that occurred during a standard 6-day phase II pasteurization and conditioning treatment were studied in a small-scale mushroom production research facility. After phase II composting, E. coli, coliforms, and Enterobacteriaceae were below detectable levels, and inoculated pathogens were not detected by direct plating or by enrichment. The results of this study show that a phase II composting process can be an effective control measure for eliminating risks associated with the use of composted animal manures during mushroom production. Growers are encouraged to validate and verify their own composting processes through periodic microbial testing for pathogens and to conduct studies to assure uniform distribution of substrate temperatures during phase II.
\end{abstract}

Increases in the number of foodborne disease outbreaks associated with fresh produce has been attributed, in part, to a shift in consumer preference toward fresh fruits and vegetables that are not subjected to high-temperature blanch or retort treatments (44). As this trend continues, there exists a need to reevaluate farm-to-table contamination risks under commercial growing and handling conditions.

Consumption statistics for mushrooms reflect overall fruit and vegetable trends. In 1970, only $28 \%$ of white button mushrooms (Agaricus bisporus) grown in the United States were marketed fresh; the remaining were sold as processed products. In contrast, $86 \%$ of the 2009 to 2010 mushroom crop was sold as fresh whole or sliced products (30). Production of A. bisporus mushrooms is highly centralized in the state of Pennsylvania, where in 2009 to 2010, 64\% of the U.S. population-consumed Agaricus mushrooms were grown.

There have been no reports to date of foodborne illness attributed to consumption of fresh commercially grown mushrooms. However, microbial surveys of fresh produce have provided evidence that mushrooms can become contaminated with Listeria spp. $(18,25,38,45,55)$,

\footnotetext{
* Author for correspondence. Tel: 814-863-2298; Fax: 814-863-6132; E-mail: 1f15@psu.edu.

$\dagger$ Present address: Del Monte Foods, 375 North Shore Drive, Pittsburgh, PA 15212, USA.
}

Salmonella spp. $(14,17,35,36,38)$, enterohemorrhagic Escherichia coli (38), and Campylobacter jejuni (14). Several recalls and consumer advisories have been issued by government agencies after detectable levels of pathogens were found on mushrooms. In 2001, government authorities in Ireland advised consumers to cook fresh mushrooms that tested positive for Salmonella Kedougou $(12,17)$. In the United States, voluntary recalls of sliced mushrooms were issued by state health agencies in Georgia (11) and Ohio (48) after Listeria monocytogenes was detected. More recently, the Canadian Food Inspection Agency ordered recalls of Canadian-grown mushrooms after detectable levels of L. monocytogenes were found (6-9).

Commercial mushroom growing is a unique form of agriculture, in that an organic medium-known in the industry as growth substrate-must be prepared prior to $A$. bisporus inoculation. Specialized composting procedures promote the growth of thermophilic microorganisms that break down complex carbon and nitrogen compounds into forms that are more nutritionally available to mushrooms. Most mushroom growers in the United States have adopted a two-step substrate preparation process known as phase I and phase II composting (1). Phase I begins as agricultural raw materials (e.g., horse and poultry manure, straw, corn cobs, brewer's grain, cotton seed hulls, cocoa bean hulls, gypsum) are thoroughly mixed, wetted, and formed into 
long rows on outdoor concrete wharfs where they are turned periodically, watered, and reformed. Alternatively, the mixture can be moved into more efficient, enclosed bunker structures in which floor vents continuously force air through the pile. With both systems, rapid thermophile growth causes core pile temperatures to reach 70 to $80^{\circ} \mathrm{C}$ within 24 to $72 \mathrm{~h}$. Phase I composting times range from 6 to 25 days, depending on the composition of the raw materials used and the efficiency of the equipment and facilities (37).

Phase II is a more controlled, indoor composting process designed to continue thermophilic breakdown of organic matter, eliminate any surviving pests and fungal pathogens, and disperse toxic ammonia gas that decrease crop yields and postharvest quality. Phase II traditionally begins when phase I substrate is moved into mushroom growing houses where the crop will eventually be grown; although more efficient enclosed tunnel structures are increasingly used for bulk substrate production (3). For both systems, the industry standard for phase II composting is to include an initial pasteurization treatment, wherein both substrate and air temperatures reach $60.0^{\circ} \mathrm{C}$ for at least $2 \mathrm{~h}$, followed by a conditioning period when gradual cooling to 48.9 to $55.4^{\circ} \mathrm{C}$ takes place for the remaining 6 to 12 days (39). Room air temperature monitoring is included in the phase II protocol to assure uniform distribution of heat throughout the substrate. Because the chemical and physical characteristics of the substrate are critical to achieving a good crop, substrate temperatures are monitored continuously and controlled by careful introduction of steam or cool, outside air. The end result is a pest-free growth substrate that contains a diverse population of beneficial thermophilic bacteria and fungi $(2,22,23,31,57)$.

After a series of food recalls and outbreaks were linked to on-farm contamination of fresh produce, the use of animal manures as agricultural soil supplements has come under increased scrutiny. Government and private agencies throughout the world have issued regulations and guidelines on hygienic composting management practices (15). The U.S. Food and Drug Administration (FDA) has issued general and commodity-specific farm food safety guidelines, known as Good Agriculture Practices (GAPs) (47, 5053). FDA GAP guidance documents include handling and application practices to prevent raw and composted animal manures from becoming a source of produce contamination. California and Arizona lettuce and spinach growers have established farm food safety standards that are emerging as a GAP program model for other commodities (34). The Leafy Greens Marketing Agreement (5) established stringent standards for the use of composted animal manure including microbial limits of $1,000 \mathrm{MPN} / \mathrm{g}$ fecal coliforms and nondetectable levels, by enrichment methods, for Salmonella spp. and E. coli O157:H7. The recently enacted Food Safety Modernization Act of 2011 (P.L. 111-353) grants the FDA authority to establish similar microbial limits for composted animal manures used on produce farms.

In response to produce safety concerns and emerging regulations, the mushroom industry, in collaboration with Penn State University, proactively developed Mushroom Good Agricultural Practices (MGAP), a set of voluntary standards for safe growing, harvesting, and handling of mushrooms (29). Among the MGAP standards required of growers who choose to participate in this program, is that substrate preparation procedures must be based on scientific principles that reduce potentially harmful microorganisms to acceptable levels. It can be expected that an FDA zero tolerance for human pathogens in composted animal manures will also apply to growth substrate prepared by mushroom growers.

Horse and poultry manure used in mushroom substrate formulations are known to be potential sources of $L$. monocytogenes (59) and Salmonella spp. (19-21), and horse manure is an infrequent source of pathogenic E. coli (26). In a recently reported microbial survey of Listeria spp. at a small-scale mushroom farm on the Penn State campus, $L$. monocytogenes was recovered from the phase I raw-material storage and composting environment (56). Although studies have been conducted on pathogen survival during animal manure composting $(15,60)$, there has been no research on the survival of human pathogens during commercial mushroom growth substrate composting. The goal of this study was therefore to determine survival characteristics of L. monocytogenes, Salmonella, and E. coli O157:H7 and selected fecal indicator organisms in mushroom growth substrate heated under temperature-controlled water bath conditions and in a small-scale phase II composting facility. The phase II pasteurization and conditioning step is the focus of this study, because it is the last point in the composting process during which a controlled and continuously monitored heat treatment is applied.

\section{MATERIALS AND METHODS}

Raw materials. Phase I substrate used for inoculation studies was obtained from the Penn State University Mushroom Test Demonstration Facility (MTDF), a small-scale mushroom research farm. The ingredients used and the proportion added by weight in the standard MTDF mixture were wheat straw-bedded horse manure $(57.1 \%)$, switch-grass straw $(5.2 \%)$, kiln-dried poultry manure $(2.0 \%)$, distiller's grain $(2.6 \%)$, gypsum $(1.6 \%)$, and water $(31.5 \%)$. The ingredients $\left(10.9 \times 10^{3} \mathrm{~kg}\right)$ were mechanically mixed and transferred to a bulk phase I bunker for a 6-day composting treatment. Core phase I pile temperatures were monitored with thermocouples embedded in the pile and controlled by continuous flow of air through a series of forced air vents on the bunker floor.

Pathogen strains and preparation of inoculum. Chickenlitter isolates of Salmonella serotypes Typhimurium (03-8970) and Heidelberg (03-8976) were obtained from the National Veterinary Services Laboratory (Ames, IA). L. monocytogenes Scott A (serotype 4b) and FSL R2-499 (serotype 1/2a, human epidemic origin) were obtained from the Penn State Food Microbiology Laboratory Collection. E. coli O157:H7 (ATCC strain 43889, American Type Culture Collection, Manassas, VA), was isolated from the feces of a patient with hemolytic uremic syndrome. Strain 93-0133 was obtained from the Penn State Food Microbiology Laboratory Collection.

Working cultures of each of the pathogens were maintained on tryptic soy agar supplemented with $0.6 \%$ yeast extract (TSAYE; Difco, BD, Sparks, MD). An isolated colony was added to $10 \mathrm{ml}$ of TSBYE and incubated 18 to $22 \mathrm{~h}$ at $35^{\circ} \mathrm{C}$. A $0.1-\mathrm{ml}$ aliquot was 
then transferred into $100 \mathrm{ml}$ of TSBYE and incubated for 18 to $22 \mathrm{~h}$ at $35^{\circ} \mathrm{C}$ to produce stationary-phase populations. Each suspension was then centrifuged for $10 \mathrm{~min}$ at 9,000 rpm (Beckman model J221 centrifuge), and the pellet was resuspended in $100 \mathrm{ml}$ of $0.85 \%$ $\mathrm{NaCl}$ solution. The six suspensions were combined as a composite culture (cocktail) containing approximately $10^{8} \mathrm{CFU} / \mathrm{ml}$ each pathogen.

Inoculation and treatment application: water bath study. Thermal inactivation studies on inoculated phase I substrate were conducted in a Department of Food Science BSL-2 microbiology laboratory. Phase I substrate $(2.5 \mathrm{~kg})$, obtained from the MTDF, was combined with the previously described pathogen cocktail (200 ml) and thoroughly mixed in a sterilized 6-liter stainless steel beaker with sterile forceps for $2 \mathrm{~min}$. Preliminary tests confirmed that the inoculum was uniformly distributed throughout the substrate. Substrate aliquots (75 g) were weighed into polypropylene bags (UltraSource, Kansas City, MO) and vacuum sealed. The dimensions of the filled and sealed bags were 12.7 by 22.9 by $0.5 \mathrm{~cm}$. The bags were heat treated by fully immersing them for up to $120 \mathrm{~min}$ in a temperature-controlled water bath (Thelco Model 84, Precision Scientific Co., Buffalo, NY) adjusted to 48.8, 54.4, or $60^{\circ} \mathrm{C}$. Temperature come-up and come-down times were determined by inserting a temperature probe (Precision 0.01 Degree, Control Co., Friendswood, TX) in the geometric center of an uninoculated filled bag. At the end of each temperature-time treatment, duplicate bags were removed and cooled in an ice water bath until the contents reached room temperature. The contents were enumerated immediately for pathogens as described below. Uninoculated bags of phase I substrate were used to follow changes in microbial indicator populations at each temperature and time. The experiment was repeated for each temperature. After inoculation experiments were completed, all substrate samples were autoclaved at $121^{\circ} \mathrm{C}$ and properly disposed.

Inoculation and treatment application: phase II composting study. Microbial inoculation and treatment protocols were reviewed by the Penn State Institutional Biosafety Committee (IBC) prior to conducting experiments (IBC no. 15454). Because the MTDF produces mushrooms for campus food service outlets, it was not possible to conduct phase II inoculation studies at this facility. Instead, finished phase I substrate was transported to the Penn State Mushroom Research Center (MRC) and into a pilotscale phase II room $\left(7.9 \mathrm{~m}^{2}\right)$ wherein precise temperature control could be maintained. Contamination risks were minimized by the fact that no mushrooms at the MRC are sold to the public, and inoculation procedures took place off-site in a Department of Food Science biosafety level II laboratory. All bags were wiped with $70 \%$ ethanol prior to leaving the laboratory.

Phase I substrate $(2.50 \mathrm{~kg})$, obtained from the MTDF, and the pathogen cocktail $(200 \mathrm{ml})$ were filled simultaneously into three polypropylene bags (4 liter; Unicorn Imp. and Mfg., Garland, TX) that are normally used for cultivating non-Agaricus specialty mushrooms. Each bag had two perforated filter patches $(3$ by $6 \mathrm{~cm}$, $0.2 \mu \mathrm{l})$ on the sides to facilitate gas exchange between the inside of the bag and the external environment. The contents of each bag were mixed thoroughly by manually inverting and massaging the bags for $2 \mathrm{~min}$. Preliminary tests confirmed that this technique was sufficient to uniformly distribute the inoculum. Two hundred milliliters of $0.85 \% \mathrm{NaCl}$ was added to a fourth bag to serve as an uninoculated control. After mixing, a 250-g sample was aseptically removed from inoculated and uninoculated bags for determination of initial populations of pathogens and indicator microorganisms, respectively. A wireless temperature probe (HOBO Water Temp
Pro, Onset Computers, Bourne, MA) was placed at the approximate center of each of the bags, and a metal twist was applied to loosely seal the contents. The bags were then transported to the MRC.

At the MRC, each of the four bags was placed in the center of a standard wooden mushroom growing tray ( 61 by 61 by $30 \mathrm{~cm}$ ). Uninoculated phase I substrate was filled around and above each bag until tray capacity was reached. The trays were stacked vertically and evenly spaced between eight additional trays of uninoculated substrate. Another stack of uninoculated trays of substrate was added to fill the room in order to facilitate consistent and controllable air temperatures. Substrate temperatures were continuously monitored by placing eight thermocouples in uninoculated substrate. Room air temperature was monitored by a single thermocouple placed in the center of the room. During phase II, as thermophilic decomposition reoccurred, a programmable temperature controller (SamStat, Landenberg, PA) was used to raise or lower substrate temperature by automatically venting steam or cool air, respectively, into the room. Pasteurization was considered complete by the MRC operator when the temperature of the air and the lowest reading probe in the substrate reached $60^{\circ} \mathrm{C}$ for $2 \mathrm{~h}$. Conditioning continued until the end of the 6-day process, after which the bags were removed from the trays and returned to the Food Science Department for enumeration of pathogens and indicator microorganisms. Levels for moisture, total carbon, and total nitrogen in uninoculated substrate were determined at the Penn State Agricultural Analytical Services Laboratory (University Park, PA) by using U.S. Department of Agriculture (USDA) standard test methods for examination of compost. Uninoculated substrate remaining in trays was disposed of on-site so that it could not be reused for other MRC experiments.

Microbiological analysis. For water bath experiments, $25 \mathrm{~g}$ of substrate was combined with $225 \mathrm{ml}$ of buffered peptone water (Difco, BD) in a variable-speed stainless steel laboratory blender (model 38BL54, Waring Laboratory, Torrington, CT) and blended for $30 \mathrm{~s}$ at medium speed. For the phase II composting study, $250 \mathrm{~g}$ of substrate was combined with $2,250 \mathrm{ml}$ of buffered peptone water in a sterilized 6-liter stainless steel beaker. The mixture was stirred by hand for $2.0 \mathrm{~min}$ with sterile forceps. Infusions obtained by both methods were serially diluted in buffered peptone water for microbial enumeration.

Aerobic plate count, E. coli, total coliforms, and Enterobacteriaceae populations in uninoculated substrate were enumerated with Petrifilm methods from 3M (St. Paul, MN) with incubation at $37^{\circ} \mathrm{C}$ for 24 h. L. monocytogenes, Salmonella spp., and E. coli O157:H7 populations were determined by spread plating $0.1 \mathrm{ml}$ on modified Oxford agar (Difco, BD), xylose lysine deoxycholate (XLD) agar (Difco, BD), or MacConkey sorbitol agar (Difco, BD), respectively, followed by incubation for 24 to $48 \mathrm{~h}$ at $35^{\circ} \mathrm{C}$. Black colonies on modified Oxford agar or XLD agar were considered presumptive positive for Listeria spp. or Salmonella spp., respectively, and were confirmed positive by using a Listeria visual immunoassay (TECRA International, Frenchs, Australia) or a latex agglutination test (Oxoid, Thermo Scientific, Waltham, MA). Presumptive-positive E. coli O157:H7 colonies on MacConkey sorbitol agar were colorless and were confirmed as positive for the $\mathrm{O} 157$ antigen by using an E. coli O157 latex agglutination test (Oxoid).

When pathogens could not be detected by direct plating, standard enrichment procedures for Listeria spp. (46), Salmonella spp. (49), and E. coli O157:H7 (54) were used to confirm complete thermal destruction. L. monocytogenes was enriched by transfer- 
TABLE 1. Destruction of Listeria monocytogenes, Escherichia coli O157:H7, and Salmonella in mushroom growth substrate held at 48.8, 54.4 , and $60.0^{\circ} \mathrm{C}$

\begin{tabular}{|c|c|c|c|c|}
\hline \multirow[b]{2}{*}{ Temp $\left({ }^{\circ} \mathrm{C}\right)$} & \multirow[b]{2}{*}{ Time $(\mathrm{h})$} & \multicolumn{3}{|c|}{ Population $(\log \mathrm{CFU} / \mathrm{g})^{a}$} \\
\hline & & Listeria monocytogenes & Eshcerichia coli $\mathrm{O} 157: \mathrm{H} 7$ & Salmonella \\
\hline \multirow[t]{10}{*}{48.8} & 0 & $7.96 \pm 0.03$ & $8.09 \pm 0.08$ & $7.69 \pm 0.02$ \\
\hline & 0.5 & $7.58 \pm 0.02$ & $7.93 \pm 0.03$ & $7.26 \pm 0.03$ \\
\hline & 1.0 & $7.30 \pm 0.21$ & $7.75 \pm 0.09$ & $7.07 \pm 0.12$ \\
\hline & 2.0 & $6.79 \pm 0.17$ & $7.35 \pm 0.08$ & $6.15 \pm 0.02$ \\
\hline & 4.0 & $5.45 \pm 0.33$ & $6.61 \pm 0.12$ & $4.66 \pm 0.41$ \\
\hline & 6.0 & $5.04 \pm 0.26$ & $6.35 \pm 0.18$ & $3.93 \pm 0.03$ \\
\hline & 12 & $3.85 \pm 0.00$ & $4.74 \pm 0.51$ & $2.50 \pm 0.05$ \\
\hline & 24 & $1.00 \pm 0.00^{b}$ & $1.00 \pm 0.00$ & $\mathrm{ND}^{c}$ \\
\hline & 36 & ND & ND & ND \\
\hline & 48 & ND & ND & ND \\
\hline \multirow[t]{9}{*}{54.4} & 0 & $7.94 \pm 0.15$ & $8.02 \pm 0.24$ & $7.44 \pm 0.28$ \\
\hline & 0.25 & $6.70 \pm 0.10$ & $6.26 \pm 0.18$ & $5.33 \pm 0.23$ \\
\hline & 0.5 & $6.20 \pm 0.03$ & $5.27 \pm 0.13$ & $3.65 \pm 0.35$ \\
\hline & 1.0 & $5.35 \pm 0.05$ & $4.28 \pm 0.72$ & $1.00 \pm 0.00$ \\
\hline & 1.5 & $4.95 \pm 0.00$ & $2.59 \pm 1.59$ & $1.00 \pm 0.00$ \\
\hline & 2.0 & $3.24 \pm 0.24$ & $1.65 \pm 0.65$ & $1.00 \pm 0.00$ \\
\hline & 4.0 & $1.00 \pm 0.00$ & $1.00 \pm 0.00$ & $1.00 \pm 0.00$ \\
\hline & 6.0 & $1.00 \pm 0.00$ & $1.00 \pm 0.00$ & $1.00 \pm 0.00$ \\
\hline & 8.0 & ND & ND & ND \\
\hline \multirow[t]{9}{*}{60.0} & 0 & $7.92 \pm 0.03$ & $8.39 \pm 0.11$ & $7.90 \pm 0.07$ \\
\hline & 0.05 & $6.20 \pm 0.08$ & $2.50 \pm 1.50$ & $1.00 \pm 0.00$ \\
\hline & 0.10 & $5.40 \pm 0.32$ & ND & ND \\
\hline & 0.15 & $4.30 \pm 0.35$ & ND & ND \\
\hline & 0.20 & $1.00 \pm 0.00$ & ND & ND \\
\hline & 0.25 & $1.00 \pm 0.00$ & ND & ND \\
\hline & 0.50 & ND & ND & ND \\
\hline & 1.0 & ND & ND & ND \\
\hline & 2.0 & ND & ND & ND \\
\hline
\end{tabular}

\footnotetext{
${ }^{a}$ Mean values obtained from two replicate experiments \pm standard deviations.

${ }^{b} 1.00 \pm 0.00$, negative by direct plating method $(<1.0 \overline{\log } \mathrm{CFU} / \mathrm{g})$, positive by enrichment method $(>1$ cell per $10 \mathrm{~g})$.

${ }^{c} \mathrm{ND}$, not detected. Negative by direct plating method $(<1.0 \log \mathrm{CFU} / \mathrm{g})$, negative by enrichment method $(<1 \mathrm{cell}$ per $10 \mathrm{~g})$.
}

ring $10 \mathrm{~g}$ of substrate to $90 \mathrm{ml}$ of UVM formulation broth (Difco, BD) and incubating at $35^{\circ} \mathrm{C}$ for $24 \mathrm{~h}$. One milliliter of the infusion was transferred to $10 \mathrm{ml}$ of Fraser broth (Difco, BD) and incubated for an additional $24 \mathrm{~h}$ at $35^{\circ} \mathrm{C}$. Loopfuls were streaked onto modified Oxford agar and incubated for $24 \mathrm{~h}$ at $35^{\circ} \mathrm{C}$. Presumptive-positive colonies appeared black and were confirmed positive for Listeria spp. by using Listeria visual immunoassay. Salmonella was enriched by adding $10 \mathrm{~g}$ of substrate to $90 \mathrm{ml}$ of lactose broth (Difco, BD) and incubating for $24 \mathrm{~h}$ at $35^{\circ} \mathrm{C}$. One milliliter was added to $10 \mathrm{ml}$ each of selenite-cysteine broth (Difco, BD) and tetrathionate broth (Difco, BD), followed by incubation for $24 \mathrm{~h}$ at $35^{\circ} \mathrm{C}$. Each broth was streaked onto XLD agar (Difco, BD). Colonies presumptively positive for Salmonella were black on XLD agar and were confirmed with latex agglutination (Oxoid). Pathogenic E. coli were enriched by transferring $10 \mathrm{~g}$ of compost to $90 \mathrm{ml}$ of brain heart infusion broth (Difco, BD) and incubating at $35^{\circ} \mathrm{C}$ for $3 \mathrm{~h}$. The broth was then decanted into $100 \mathrm{ml}$ of doublestrength tryptose phosphate broth (Difco, BD) and incubated $20 \mathrm{~h}$ at $44^{\circ} \mathrm{C}$. After incubation, loopfuls were streaked onto MacConkey sorbitol agar and incubated $24 \mathrm{~h}$ at $35^{\circ} \mathrm{C}$. Presumptive-positive colonies appeared colorless and were confirmed with latex agglutination (Oxoid).

Statistical analysis. Bacterial populations were converted to $\log$ CFU per gram. Analysis of variance and mean separation analysis by using Tukey's honestly significant difference at the $\alpha=0.05$ level were used to compare bacteria levels obtained from the mean of two replicate water bath or MRC experiments. Regression analysis was performed to determine death rates for microorganisms.

\section{RESULTS}

Water bath study. Substrate inoculated with $L$. monocytogenes, E. coli O157:H7, and Salmonella was held in vacuum-sealed polypropylene bags to prevent moisture loss during extended heating and to allow precise control of temperature and time treatments. Temperature come-up times for substrate held in a water bath at 48.8, 54.4, and $60.0^{\circ} \mathrm{C}$ were $4.5,5.0$, and $5.0 \mathrm{~min}$, respectively. Initial levels of the three pathogens were between 7.4 and $8.4 \mathrm{log}$ $\mathrm{CFU} / \mathrm{g}$. Population levels for each of the pathogens during heating at each of the three temperatures are shown in Table 1. Thermal destruction of each of the pathogens was affected significantly $(P \leq 0.05)$ by heating temperature and time. Salmonella and E. coli O157:H7 appeared to be less heat resistant than L. monocytogenes; however, there were not enough data points at $60^{\circ} \mathrm{C}$ to make statistically valid comparisons of thermal activation rates for all temperatures. 
TABLE 2. Decimal reduction times (D-values) at $54.4{ }^{\circ} \mathrm{C}$ for destruction of Listeria monocytogenes, Escherichia coli O157:H7, and Salmonella in inoculated substrate and indicator organisms in uninoculated substrate

\begin{tabular}{lc}
\hline \multicolumn{1}{c}{ Microorganism } & $D_{54.4}$-value (min) \\
\hline Listeria monocytogenes & $27.0 \mathrm{~A}^{a}$ \\
Escherichia coli $0157: \mathrm{H} 7$ & $22.1 \mathrm{~A}$ \\
E. coli & $13.9 \mathrm{~B}$ \\
Total coliforms & $13.9 \mathrm{~B}$ \\
Enterobacteriaceae & $13.5 \mathrm{~B}$ \\
Salmonella & $10.8 \mathrm{~B}$ \\
\hline
\end{tabular}

${ }^{a}$ Mean values obtained from two replicate experiments followed by the same letter are not significantly different $(\alpha=0.05)$.

Minimum times at which all three of the pathogens were not detectable by plating and enrichment were $36.0,8.0$, and $0.5 \mathrm{~h}$ at $48.8,54.4$, and $60^{\circ} \mathrm{C}$, respectively.

Destruction of indicator microorganisms and pathogens were followed at $54.4^{\circ} \mathrm{C}$ so that enough data points could be generated to make statistically valid rate comparisons. Pretreatment populations of E. coli, total coliforms, and Enterobacteriaceae were 5.4 to $6.0 \mathrm{log} \mathrm{CFU} / \mathrm{g}$. Therefore, initial pathogen inoculum levels were adjusted to a similar range of 5.0 to $6.0 \log \mathrm{CFU} / \mathrm{g}$ (individual data not shown).

Linear $\log$ reductions for each of the microbial indicators and pathogens at $54.4^{\circ} \mathrm{C}$ for up to $2 \mathrm{~h}$ were observed, as evidenced by greater than $0.9 R^{2}$ values for each type or species. Microbial heat resistance was therefore compared by calculating decimal reduction times at $54.4^{\circ} \mathrm{C}$

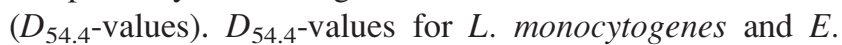
coli $\mathrm{O} 157: \mathrm{H} 7$ were significantly $(P \leq 0.05)$ higher than for Salmonella and for E. coli, total coliforms, and Enterobacteriaceae indicator microorganisms (Table 2).

Phase II composting study. A representative plot of temperature changes that occurred within bags of substrate during the 6-day (144 h) phase II MRC process is shown in Figure 1. Remote probe readings from within inoculated bags were consistent with process control measurements taken directly from trays of uninoculated substrate. The pasteurization interval, during which the operator verified that substrate and room air temperatures increased to at least $60^{\circ} \mathrm{C}$ for $2 \mathrm{~h}$, began approximately $24 \mathrm{~h}$ after phase II began. During the conditioning interval that followed, introduction of cool air into the room lowered substrate temperatures to between 46 and $53^{\circ} \mathrm{C}$. After phase II composting, the substrate contained $77.2 \%$ moisture, $36.2 \%$ total carbon (dry weight basis), and $1.8 \%$ total nitrogen (dry weight basis) $(\mathrm{C}: \mathrm{N}=20.1)$.

Data for the destruction of naturally occurring indicator microorganisms and inoculated pathogens during phase II composting are shown in Table 3. Microbial populations were only determined immediately before and after composting, because entry into the phase II room was not permitted once it was sealed. No pathogens were found in any of the uninoculated samples. Initial levels of $L$. monocytogenes, Salmonella, and E. coli O157:H7 after

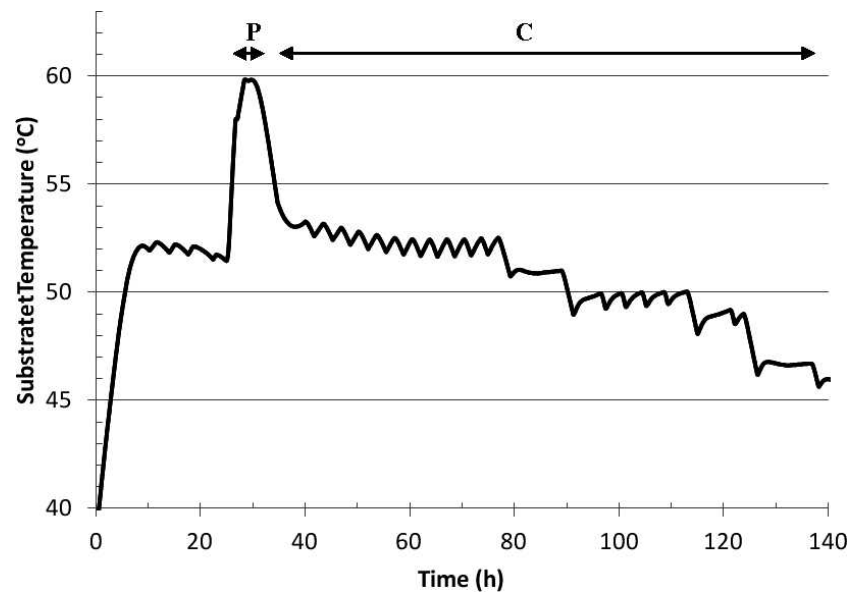

FIGURE 1. Representative plot of substrate temperatures taken during phase II composting. Plot line represents the average temperature reading taken from four bags every $0.1 \mathrm{~h}$. Pooled standard deviation $=1.4^{\circ} \mathrm{C}$. $P$, pasteurization; $C$, conditioning.

inoculation ranged from 7.2 to $8.1 \log \mathrm{CFU} / \mathrm{g}$. After phase II composting, none of the pathogens were detected by direct plating or by enrichment.

Despite phase I core pile temperatures of up to $80^{\circ} \mathrm{C}$, populations of E. coli, coliforms, and Enterobacteriaceae prior to phase II composting were between 4 and $6 \log \mathrm{CFU} / \mathrm{g}$ (Table 3). Destruction of the three microbial indicators followed that of the three pathogens. All were below detectable levels after phase II composting. In contrast, aerobic plate count populations, initially at nearly $9 \log \mathrm{CFU} / \mathrm{g}$, decreased by less than $2 \log \mathrm{CFU} / \mathrm{g}$ during phase II composting.

\section{DISCUSSION}

The $D_{54.4}$-values determined in the water bath study are within ranges reported in several studies on the destruction of the same pathogens in meat and poultry heated at 54 to $56^{\circ} \mathrm{C}$ $(13,28,32,33)$. The $D_{54.4}$-value for destruction of $E$. coli O157:H7 in mushroom substrate is comparable to the $D_{55^{-}}$ value of $35.4 \mathrm{~min}$ reported for composted dairy manure by Jiang et al. (24). The more rapid destruction of E. coli, total coliforms, and Enterobacteriaceae compared with L. monocytogenes and E. coli $\mathrm{O} 157: \mathrm{H} 7$ at $54.4^{\circ} \mathrm{C}$ indicate that fecal indicators are not appropriate for predicting pathogen destruction during phase II composting.

The high levels of E. coli, total coliforms, and Enterobacteriaceae in substrate used for phase II inoculation studies confirms our assumption that phase I composting is not an adequate microbial hurdle for eliminating pathogens associated with horse and poultry manure. It is likely that during phase I, uneven distribution of heat within the pile occurred, which resulted in areas where temperatures were low enough to permit survival of mesophilic bacteria.

The absence of recoverable pathogens and less than detectable levels of microbial indicators after phase II composting is a reasonable result, given the temperature history data from which Figure 1 was derived. The time during MRC composting experiments at which all substrate temperature measurements were at or above $60^{\circ} \mathrm{C}$ was $1.9 \mathrm{~h}$, 
TABLE 3. Destruction of Listeria monocytogenes, Escherichia coli O157:H7, and Salmonella in inoculated substrate and indicator microorganisms in uninoculated substrate during phase II composting

Microbial population $(\log \mathrm{CFU} / \mathrm{g})^{a}$

After phase I

After phase II

Inoculated pathogens

Listeria monocytogenes

Escherichia coli O157:H7

Salmonella

$\begin{array}{ll}7.95 \pm 0.21 & \mathrm{ND}^{b, c, d} \\ 7.95 \pm 0.21 & \mathrm{ND}^{b, c} \\ 7.40 \pm 0.28 & \mathrm{ND}^{b, c}\end{array}$

Indicator organisms

E. coli

$4.70 \pm 0.14$

$\mathrm{ND}^{b}$

Total coliforms

$5.10 \pm 0.28$

$5.80 \pm 0.28$

$\mathrm{ND}^{b}$

Enterobacteriaceae

$8.75 \pm 0.35$

$\mathrm{ND}^{b}$

Aerobic plate count

$6.90 \pm 0.43$

${ }^{a}$ Mean \pm standard deviation of the mean population of bacteria. Populations were significantly different before and after phase II composting for all microorganisms $(\alpha=0.05)$.

${ }^{b}$ Negative by the direct plating method $(<1.0 \log \mathrm{CFU} / \mathrm{g})$.

${ }^{c}$ Negative by the enrichment method $(<1$ cell per $10 \mathrm{~g})$.

${ }^{d} \mathrm{ND}$, not detected.

while the water bath study (Table 1) showed that only $0.5 \mathrm{~h}$ at $60^{\circ} \mathrm{C}$ was required to achieve complete destruction of all pathogens. Moreover, the contribution of the conditioning period to the total lethality of the phase II process should be considered. The time substrate was exposed to temperatures ranges of 48.8 to 54.3 and 54.4 to $59.9^{\circ} \mathrm{C}$ was 21 and $5 \mathrm{~h}$, respectively. According to Table 1, each of these temperature and time conditions is individually severe enough to achieve complete pathogen destruction. Thus, the total lethality achieved during MRC phase II composting was far more severe than required to achieve complete destruction of each of the inoculated pathogens. Absence of detectable levels of E. coli, total coliforms, and Enterobacteriaceae after phase II is also not unexpected given the more rapid destruction of these fecal indicators compared with L. monocytogenes and E. coli O157:H7 (Table 2). High aerobic plate count levels before and after phase II composting can be attributed to selective survival of nonpathogenic thermophilic bacteria and fungi during prolonged exposure to phase II temperatures $(22,23,31$, 57).

Results from the water bath and MRC phase II composting studies demonstrate that on-farm verification of phase II composting as an effective food safety control method can only be achieved by testing for the most heatresistant pathogens in substrate, which this study has shown are L. monocytogenes and/or E. coli O157:H7.

Although the phase II method used in this study is the standard procedure used in the mushroom industry (2), actual microbial reductions achieved can differ among farms. In general, differences in microbial heat resistance have been attributed to chemical and physical characteristics of the matrix tested (13). During composting, pathogen destruction rates are influenced by the $\mathrm{C}: \mathrm{N}$ ratio of the ingredient mixture; the amount of volatile acids, free ammonia, and moisture present; microflora levels; and temperature gradients within piles $(15,60)$. Differences in the types of raw materials and their proportion in mushroom growth substrate can affect chemical, physical, and microbiological characteristics of formulations and thus the amount of heat generated during composting. The moisture content of the phase II substrate was higher and the C:N ratio was lower than optimal levels for pathogen reduction reported in studies of other types of agricultural composting systems $(42,43)$. However, these levels are within the expected range that occurs on commercial mushroom farms $(3,39)$. Further experiments on the kinetics of pathogen inactivation as affected by moisture and $\mathrm{C}: \mathrm{N}$ ratio were not conducted, because the mushroom composting process has been optimized for A. bisporus crop yield and quality, and any deviation from well-established protocols would likely be unacceptable to the industry.

It should be noted that the pathogen inoculum used for the experiments in this study, was prepared from cultures grown in the laboratory at $35^{\circ} \mathrm{C}$. On commercial farms, any pathogenic bacteria that survive phase I composting would likely to have been exposed to high, but sublethal, temperatures. Several model system and food studies have demonstrated increased thermotolerance of L. monocytogenes, E. coli $\mathrm{O} 157: \mathrm{H7}$, and Salmonella spp. initially exposed to sublethal temperatures between 40 and $52^{\circ} \mathrm{C}$ $(4,10,16,27,40)$. Singh et al. (41) reported that thermal resistance of L. monocytogenes, E. coli $\mathrm{O} 157: \mathrm{H} 7$, and Salmonella spp. in dairy compost was higher if the inoculum was first heat shocked at $47.5^{\circ} \mathrm{C}$ for $1 \mathrm{~h}$. Therefore, it is possible that any pathogens present in phase I ingredients are more resistant to phase II composting temperatures than those used in the inoculum for this study. The growth stage of pathogens used to prepare the inoculum might also affect thermotolerance (58). Further studies could be conducted with pathogen cultures grown at different life cycle stages and that have been heat adapted at sublethal temperatures that occur during phase I composting prior to inoculation. Varying inoculation levels would also be useful to compare the efficacy of phase II composting over a wide range of initial pathogen populations.

Nevertheless, the observed $\geq 7-\log$ reductions in $L$. monocytogenes, E. coli $\mathrm{O} 157: \mathrm{H} 7$, and Salmonella show that a phase II composting process can be an effective food safety control measure that meets stringent microbial standards for composted animal manures, including those established by the Leafy Greens Marketing Agreement (5) and FDA composting regulations.

Although safety considerations preclude pathogen inoculation studies on commercial farms, growers should collect additional data to validate their own phase II composting process. Growers should consider that substrate temperature gradients can exist in growing rooms or in tunnels, and studies should be conducted to detect any cold spots during phase II composting. Temperature monitoring probes should be placed in these areas to assure that lethal temperatures reach every part of the substrate. 
Growers can take steps to verify that a phase II composting process is consistently applied by regularly reviewing temperature profile records and by testing substrate for L. monocytogenes at least once per year or anytime major changes are made to the type and proportion of raw materials used. Because temperature monitoring and control equipment are important for obtaining consistent phase II heat treatments, they should be regularly maintained and calibrated to ensure that readings are accurate.

Where phase I composting is conducted at the same location as growing operations, MGAP standards for preventing cross-contamination should be adhered to. These include keeping areas where horse and poultry manure are received, stored, and handled physically separated from mushroom growing areas and controlling the movement of equipment and workers between these areas.

\section{ACKNOWLEDGMENT}

This study was partially funded by USDA, Cooperative State Research, Education, and Extension Service agreement no. 2001-5111011370.

\section{REFERENCES}

1. Beyer, D. M. 2003. Basic procedures for Agaricus mushroom growing. College of Agricultural Sciences. The Pennsylvania State University, University Park.

2. Beyer, D., and J. A. Pecchia. 2010. Microbes of phase II. Mushroom News 58:14-15.

3. Beyer, D. M., R. Rynk, J. Pecchia, and P. Wuest. 2000. Improving odor management on mushroom farms. Biocycle 41:60-63.

4. Bunning, V. K., R. G. Crawford, J. T. Tierney, and J. T. Peeler. 1990. Thermotolerance of Listeria monocytogenes and Salmonella typhimurium after sublethal heat shock. Appl. Environ. Microbiol. 56: 3216-3219.

5. California Leafy Green Handler Marketing Board. 2012. Leafy Greens Marketing Agreement. Commodity specific food safety guidelines for the production and harvest of leafy greens. California Leafy Green Products Handler Marketing Agreement. Available at: http://www.caleafygreens.ca.gov. Accessed 4 February 2013.

6. Canadian Food Inspection Agency. 2008. Health hazard: various sliced mushroom products may contain Listeria monocytogenes. Canadian Food Inspection Agency. Available at: http://epe.lac-bac. gc.ca/100/206/301/cfia-acia/2011-09-21/www.inspection.gc.ca/english/ corpaffr/recarapp/2008/20080801ce.shtml. Accessed 4 February 2013.

7. Canadian Food Inspection Agency. 2011. Health hazard alert: certain sliced mushrooms may contain Listeria monocytogenes. Available at: http://www.inspection.gc.ca/english/corpaffr/recarapp/2011/20111210e. shtml. Accessed 4 February 2013.

8. Canadian Food Inspection Agency. 2012. Health hazard alert: certain sliced mushrooms may contain Listeria monocytogenes. Available at: http://www.inspection.gc.ca/english/corpaffr/recarapp/2012/20120813e. shtml. Accessed 4 February 2013.

9. Canadian Food Inspection Agency. 2012. Health hazard alert: certain Champs's mushrooms brand sliced Crimini mushrooms may contain Listeria monocytogenes. Available at: http://www.inspection.gc.ca/ english/corpaffr/recarapp/2012/20120927ce.shtml. Accessed 4 February 2013.

10. Cebrian, G., N. Sagarzazu, R. Pagan, S. Condon, and P. Manas. 2008. Resistance of Escherichia coli grown at different temperatures to various environmental stresses. J. Appl. Microbiol. 105:271-278.

11. Defense Logistics Agency. 2003. Georgia Ag. Department finds contaminated mushrooms. DSCP vendor recall 022-2003. U.S. Department of Defense. Available at: http://www.troopsupport.dla. mil/subs/fso/alfood/2003/vend2203.pdf. Accessed 4 February 2013.

12. Doran, G., F. Sheridan, N. Delappe, C. O'Hare, W. Anderson, G. Corbett-Feeney, and M. Cormican. 2005. Salmonella enterica serovar
Kedougou contamination of commercially grown mushrooms. Diagn. Microbiol. Infect. Dis. 51:73-76.

13. Doyle, M. E., A. S. Mazzotta, T. Wang, D. W. Wiseman, and V. N. Scott. 2001. Heat resistance of Listeria monocytogenes. J. Food Prot. 64:410-429.

14. Doyle, M. P. and J. L. Schoeni. 1986. Isolation of Campylobacter jejuni from retail mushrooms. Appl. Environ. Microbiol. 51:449-450.

15. Erickson, M., F. Critzer, and M. Doyle. 2010. Composting criteria for animal manure. Produce Safety Project Issue Brief. Pew Charitable Trusts. Available at: http://www.pewhealth.org/uploadedFiles/PHG/ Content_Level_Pages/Issue_Briefs/PSP_PEW-PSP-CompostingManure-Narrative-v4-2.pdf. Accessed 4 February 2013.

16. Farber, J. M., and B. E. Brown. 1990. Effect of prior heat shock on heat resistance of Listeria monocytogenes in meat. Appl. Environ. Microbiol. 56:1584-1587.

17. Food Safety Authority of Ireland. 2003. Advisory Committee on the Microbiological Safety of Food-Raw mushrooms: consumer advice. Available at: http://www.food.gov.uk/multimedia/pdfs/acm655.pdf. Accessed 6 May 2013.

18. Heisick, J. E., D. E. Wagner, M. L. Nierman, and J. T. Peeler. 1989. Listeria spp. found on fresh market produce. Appl. Environ. Microbiol. 55:19251927.

19. Heuvelink, A. E., J. T. Zwartkruis-Nahuis, F. L. Van Den Biggelaar, and E. Deboer. 1996. Isolation and characterization of verocytotoxinproducing Escherichia coli $\mathrm{O} 157$ from slaughter pigs and poultry. Int . J. Food Microbiol. 52:67-75.

20. Himathongkham, S., and H. Riemann. 1999. Destruction of Salmonella typhimurium, Escherichia coli $\mathrm{O} 157: \mathrm{H} 7$ and Listeria monocytogenes in chicken manure by drying and/or gassing with ammonia. FEMS Microbiol. Lett. 171:179-182.

21. Himathongkham, S., H. Riemann, S. Bahari, S. Nuanualsuwan, P. Kass, and D. O. Cliver. 2000. Survival of Salmonella typhimurium and Escherichia coli O157:H7 in poultry manure and manure slurry at sublethal temperatures. Avian Dis. 44:853-860.

22. Ivors, K., D. Beyer, P. Wuest, and S. Kang. 2002. Survey of fungal diversity in mushroom compost using sequences of PCR-amplified genes encoding $18 \mathrm{~S}$ ribosomal RNA, p. 17-24. In $\mathrm{H}$. Insam, N. Riddech, and S. Klammer (ed.), Microbiology of composting. Springer, New York.

23. Ivors, K. L., P. D. Collopy, D. M. Beyer, and S. Kang. 2000. Identification of bacteria in mushroom compost using ribosomal RNA sequence. Compost Sci. Util. 8:247-253.

24. Jiang, X., J. Morgan, and M. P. Doyle. 2003. Thermal inactivation of Escherichia coli $\mathrm{O} 157: \mathrm{H} 7$ in cow manure compost. J. Food Prot. 66: 1771-1777.

25. Junttila, J., and M. Brander. 1989. Listeria monocytogenes septicemia associated with consumption of salted mushrooms. Scand. J. Infect. Dis. 21:339-342.

26. Lengacher, B., T. R. Kline, L. Harpster, M. L. Williams, and J. T. Lejeune. 2010. Low prevalence of Escherichia coli O157:H7 in horses in Ohio, USA. J. Food Prot. 73:2089-2092.

27. Linton, R. H., J. B. Webster, J. D. Pierson, J. R. Bishop, and C. R. Hackney. 1992. The effect of sublethal heat shock and growth atmosphere on the heat resistance of Listeria monocytogenes Scott A. J. Food Prot. 55:84-87.

28. Murphy, R. Y., E. M. Martin, L. K. Duncan, B. L. Beard, and J. A. Marcy. 2004. Thermal process validation for Escherichia coli O157:H7, Salmonella, and Listeria monocytogenes in ground turkey and beef products. J. Food Prot. 67:1394-1402.

29. Mushroom Good Agricultural Practices. 2010. Mushroom Good Agricultural Practices-industry-wide food safety standards for fresh mushroom growing, harvesting, and shipping. American Mushroom Institute and Penn State University. Available at: http://www.mgap. org. Accessed 4 February 2013.

30. National Agricultural Statistics Service 2011. National Agricultural Statistics Service Vegetables and Melons Outlook: mushrooms. VGS344. USDA Economic Research Service, Washington, D.C.

31. Ntougias, S., G. I. Zervakis, N. Kavroulakis, C. Ehaliotis, and K. K. Papadopoulou. 2004. Bacterial diversity in spent mushroom compost assessed by amplified rDNA restriction analysis and sequencing of cultivated isolates. Syst. Appl. Microbiol. 27:746-754. 
32. Orta-Ramirez, A., and D. M. Smith. 2002. Thermal inactivation of pathogens and verification of adequate cooking in meat and poultry products. Adv. Food Nutr. Res. 44:147-194.

33. Osaili, T., C. L. Griffis, E. M. Martin, B. L. Beard, A. Keener, and J. A. Jarcy. 2006. Thermal inactivation studies of Escherichia coli O157:H7, Salmonella, and Listeria monocytogenes in ready-to-eat chicken-fried beef patties. J. Food Prot. 69:1080-1086.

34. Palma, M. A., L. A. Ribera, M. Paggi, and R. Knutson. 2010. Food safety standards for the U.S. fresh produce industry. Policy Issues P18:1-6.

35. Riemann, H., S. Himathongkham, D. Willoughby, R. Tarbell, and R. Breitmeyer. 1998. A survey for Salmonella by drag swabbing manure piles in California egg ranches. Avian Dis. 42:67-71.

36. Rossouw, W., E. du Plessis, and L. Korsten. 2012. Microbiological quality and safety of whole white button mushrooms (Agaricus bisporus), p. 4-9. The Spawn Run. South African Mushroom Farmers' Association, Cape Town.

37. Royse, D. J., and R. B. Beelman. 2006. Six steps to mushroom farming, 2nd ed. Pennsylvania State University College of Agricultural Sciences. Available at: http://extension.psu.edu/mushroomgrower-info/publications/guides/SixSteps.pdf/view. Accessed 4 February 2013.

38. Samadpour, M., M. W. Barbour, T. Nguyen, T. M. Cao, F. Buck, G. A. Depavia, E. Mazengia, P. Yang, D. Alfi, M. Lopes, and J. D. Stopforth. 2006. Incidence of enterohemorrhagic Escherichia coli, Escherichia coli O157, Salmonella, and Listeria monocytogenes in retail fresh ground beef, sprouts, and mushrooms. J. Food Prot. 69: $441-443$.

39. Schisler, L. C. 1982. Biochemical and mycological aspects of mushroom composting, p. 3-10. In P. J. Wuest (ed.), Penn State handbook for mushroom growers. Penn State University, University Park.

40. Sergelidis, D., and A. Abrahim. 2009. Adaptive response of Listeria monocytogenes to heat and its impact on food safety. Food Control 20:1-10.

41. Singh, R., X. Jiang, and F. Luo. 2010. Thermal inactivation of heat-shocked Escherichia coli 0157:H7, Salmonella, and Listeria monocytogenes in dairy compost. J. Food Prot. 73:1633-1640.

42. Singh, R., J. Kim, and X. Jiang. 2012. Heat inactivation of Salmonella spp. in fresh poultry compost by simulating early phase of composting process. J. Appl. Microbiol. 112:927-935.

43. Singh, R., J. Kim, M. W. Shepherd, Jr., F. Luo, and X. Jiang. 2011. Determining thermal inactivation of Escherichia coli $\mathrm{O} 157: \mathrm{H} 7$ in fresh compost by simulating early phases of the composting process. Appl. Environ. Microbiol. 77:4126-4135.

44. Sivapalasingam, S., C. R. Friedman, L. Cohen, and R. V. Tauxe. 2004. Fresh produce: a growing cause of outbreaks of foodborne illness in the United States, 1973 through 1997. J. Food Prot. 67: 2342-2353.

45. Strapp, C. M., A. E. H. Shearer, and R. D. Joerger. 2003. Survey of retail alfalfa sprouts and mushrooms for the presence of Escherichia coli $\mathrm{O} 157: \mathrm{H7}$, Salmonella, and Listeria with BAX, and evaluation of this polymerase chain reaction-based system with experimentally contaminated samples. J. Food Prot. 66:182-187.

46. U.S. Department of Agriculture, Food Safety and Inspection Service. 2007. Isolation and identification of Listeria monocytogenes from red meat, poultry, egg, and environmental samples. U.S. Department of Agriculture, Food Safety and Inspection Service, Office of Public Health Science, Washington, D.C.
47. U.S. Food and Drug Administration. 1998. Guide to minimize microbial food safety hazards for fresh fruits and vegetables. Center for Food Safety and Applied Nutrition. Available at: http://www.fda.gov/ Food/GuidanceRegulation/GuidanceDocumentsRegulatoryInformation/ ProducePlantProducts/ucm064574.htm. Accessed 6 May 2013.

48. U.S. Food and Drug Administration. 2006. Monterey Mushrooms recalls fresh sliced white and baby Bella mushrooms in PA, MD, NC, $\mathrm{NJ}, \mathrm{NY}, \mathrm{OH}$, and VA because of possible health risk. Washington, D.C. Available at: http://www.fda.gov/Safety/Recalls/ArchiveRecalls/ 2006/ucm112040.htm. Accessed 4 February 2013.

49. U.S. Food and Drug Administration. 2007. Salmonella, chap. 5. In Bacteriological analytical manual, 7th ed. U.S. Food and Drug Administration, Arlington, VA.

50. U.S. Food and Drug Administration. 2008. Guidance for industry: guide to minimize microbial food safety hazards of fresh-cut fruits and vegetables. Available at: http://www.fda.gov/Food/Guidance Regulation/GuidanceDocumentsRegulatoryInformation/ProducePlant Products/ucm064458.htm. Accessed 6 May 2013.

51. U.S. Food and Drug Administration. 2009. Guidance for industry: guide to minimize microbial food safety hazards of tomatoes; draft guidance. Available at: http://www.fda.gov/Food/GuidanceRegulation/ GuidanceDocumentsRegulatoryInformation/ProducePlantProducts/ ucm173902.htm. Accessed 6 May 2013.

52. U.S. Food and Drug Administration. 2009. Guidance for industry: guide to minimize microbial food safety hazards of leafy greens; draft guidance. Available at: http://www.fda.gov/Food/GuidanceRegulation/ GuidanceDocumentsRegulatoryInformation/ProducePlantProducts/ ucm174200.htm. Accessed 6 May 2013.

53. U.S. Food and Drug Administration. 2009. Guidance for industry: guide to minimize microbial food safety hazards of melons; draft guidance. Available at: http://www.fda.gov/Food/GuidanceRegulation/ GuidanceDocumentsRegulatoryInformation/ProducePlantProducts/ ucm174171.htm. Accessed 6 May 2013.

54. U.S. Food and Drug Administration. 2011. Diarrheagenic Escherichia coli, chap 4A. In Bacteriological analytical manual, 8th ed. U.S. Food and Drug Administration, Arlington, VA.

55. van Netten, P., I. Perales, A. Van De Moosdijk, G. D. W. Curtis, and D. A. A. Mossel. 1989. Liquid and solid selective differential media for the detection and enumeration of $L$. monocytogenes and other Listeria spp. Int. J. Food Microbiol. 8:299-316.

56. Viswanath, P., L. Murugesan, S. J. Knabel, B. Verghese, N. Chikthimmah, and L. F. LaBorde. 2013. Incidence of Listeria monocytogenes and Listeria spp. in a small-scale mushroom production facility. J. Food Prot. 76:608-615.

57. Watabe, M., J. R. Rao, J. Xu, B. C. Millar, R. F. Ward, and J. E. Moore. 2004. Identification of novel eubacteria from spent mushroom compost (SMC) waste by DNA sequence typing: ecological considerations of disposal on agricultural land. Waste Manag. 24:8186.

58. Wen, J., R. C. Anantheswaran, and S. J. Knabel. 2009. Changes in barotolerance, thermotolerance, and cellular morphology throughout the life cycle of Listeria monocytogenes. Appl. Environ. Microbiol. 75:1581-1588.

59. Wesley, I. V. 2007. Listeriosis in animals, chap. 3, p. 55-84. In E. T. Ryser and E. H. Marth (ed.), Listeria, listeriosis, and food safety. CRC Press, Boca Raton, FL.

60. Wichuk, K. M., and D. McCartney. 2007. A review of the effectiveness of current time-temperature regulations on pathogen inactivation during composting. J. Environ. Eng. Sci. 6:573-586. 